\title{
Synthesis of a Key Intermediate for the Preparation of FTY720 Analogs
}

\author{
Maiko Hamada, ${ }^{*, a, b}$ Kunitomo Adachi, ${ }^{b}$ Hidemasa Hikawa, ${ }^{a}$ and Yuusaku Yokoyama ${ }^{a}$ \\ ${ }^{a}$ School of Pharmaceutical Science, Toho University; Funabashi, Chiba 274-8510, Japan: and ${ }^{b}$ Medicinal Chemistry \\ Research Laboratories I, Research Division, Mitsubishi Tanabe Pharma Corporation; 1000 Kamoshida-cho, Aoba-ku, \\ Yokohama, Kanagawa 227-0033, Japan. Received May 25, 2012; accepted August 4, 2012
}

A concise synthesis of a useful intermediate 10 for the preparation of fingolimod (FTY-720) analogs was achieved by utilizing a chemoselective Sonogashira reaction of trihalobenzene 12 with alkyne 13 . The reaction proceeded with high selectivity to give alkyne 11 containing the dihalobenzene moiety in good yield. Compound 11 was converted into intermediate 10 by hydrogenation without reduction of the halogen atoms.

Key words fingolimod; KRP-203; palladium; chemoselectivity; cross-coupling

Pd-catalyzed cross-coupling reactions, such as the Suzuki, Heck, and Sonogashira reactions, are useful for construction of aralkyl skeletons. These reactions are commonly used in the field of drug discovery because a variety of compounds can often be provided in a short-step synthesis using commercially available reagents in combination with properly designed reaction partners (alkenes, alkynes, and boronic acids). ${ }^{1,2)}$

Fingolimod $^{3-6)}$ (FTY720, Fig. 1) is the first of a novel class of sphingosine 1-phosphate (S1P) receptor modulators and has been approved in the U.S., Russia, Switzerland, Australia and the EU to date as a first-line treatment for relapsing forms of multiple sclerosis (MS). The FTY720 analog KRP-2037) (2) showed a potent immunomodulating effect comparable to $\mathbf{1}$. Compound $\mathbf{2}$ is distinguished by having a chlorine atom on the phenyl ring close to the 2-aminopropane-1,3-diol group. Moreover, we have reported that the introduction of a chlorine atom at the same position in related analogs improved the in vivo activity (compounds 3,4$){ }^{8}{ }^{8}$ Thus, it is important to produce an intermediate having a benzene ring with an $o$ chlorine substituent in order to provide the next generation of S1P receptor modulators.

Compounds 2, 3, and $\mathbf{4}$ were synthesized from common intermediate $10{ }^{8-10)}$ However, twelve steps were required to obtain $\mathbf{1 0}$ using our previous synthetic route, as shown in Chart 1 (overall yield 22\%). ${ }^{11)}$ The starting 4-bromo-2-chlorobenzoic acid (5) was converted to homologous compound $\mathbf{6}$ in 5 steps. Condensation of diethyl malonate analog 8 with 7 , which was obtained from 6 in 3 steps, led to a side reaction forming the corresponding styrene derivative by competitive elimination resulting in the formation of 9 in low yield.

In this paper, we present a short-step synthesis of intermediate 10 using a chemoselective Pd-catalyzed cross-coupling reaction. The retrosynthetic strategy for the preparation of $\mathbf{1 0}$ is shown in Chart 2. Using this sequence, $\mathbf{1 0}$ can be obtained from 11 by hydrogenation followed by protecting group exchange. Alkyne 11 can be prepared by a chemoselective Sonogashira reaction of trihalobenzene $\mathbf{1 2}$ having different halogen atoms and alkyne $\mathbf{1 3}$ having all the required carbon fragments. This route eliminated the elongation steps required to form the aralkyl fragment and avoided the side reaction that generated the styrene derivative.

A Sonogashira reaction of 1-iodo-4-octylbenzene with alkyne $\mathbf{1 3}$ for the synthesis of $\mathbf{1}$ and chemoselective Sonogashira

The authors declare no conflict of interest.

reactions of trihalobenzene $\mathbf{1 2}$ with cyclopropylacetylene or 1-hexyne have already been reported. ${ }^{12,13)}$ On the basis of these reports, we initiated the synthesis of $\mathbf{1 0}$ as shown in Chart 3.

A chemoselective Sonogashira reaction between $\mathbf{1 2}$ and $\mathbf{1 3}$ was examined. The optimization results for this key step are summarized in Table 1 . In the synthesis of analogs of $10,{ }^{14)}$ we successfully adopted a Sonogashira coupling reaction where 2-dicyclohexylphosphino-2',4',6'-triisopropylbiphenyl (X-Phos) was used in the presence of dichlorobis(triphenylphosphine)palladium at $80^{\circ} \mathrm{C}$. First, we tried the reaction at $50^{\circ} \mathrm{C}$ because we were apprehensive that high temperature $\left(80^{\circ} \mathrm{C}\right)$ might lead to a decrease in selectivity between halogen atoms; however, the reaction did not proceed at all (run 1). Raising temperature from 50 to $80^{\circ} \mathrm{C}$ failed to give the desired compound 11 , only producing compound 14 (run 2). Since these results showed that the desired product $\mathbf{1 1}$ reacted with $\mathbf{1 3}$ more quickly than with 12, we changed the ligand from X-phos to triphenylphosphine in expectation of reducing the formation of 14 (runs $3,4)$. The combination of $\mathrm{Pd}\left(\mathrm{PPh}_{3}\right)_{4}$ and $\mathrm{CuI}$ employed for the synthesis of $\mathbf{1}^{12)}$ gave the desired product $(\mathbf{1 1}, 53 \%)$ along with the starting material $(\mathbf{1 2}, 25 \%)$ without producing byproduct 14 (run 3). Moreover, by using Bytschokov's reaction conditions using a secondary amine $(i-\mathrm{PrNH})^{13)}$ the reaction proceeded promptly and chemo-selectively to give the desired product 11 in $94 \%$ yield (run 4).

Target compound $\mathbf{1 0}$ was obtained from $\mathbf{1 1}$ in a straightforward manner as shown in Chart 4. Fortunately, hydrogenation of the internal alkyne of $\mathbf{1 1}$ over $\mathrm{PtO}_{2}$ in a $\mathrm{H}_{2}$ atmosphere gave saturated compound $\mathbf{1 5}$ without reduction of the halogen atoms. Product 15 was a mixture of desired compound 15a and tert-butoxycarbonyl ( $t$-Boc) deprotected $\mathbf{1 5 b}$. Treatment of the mixture with concentrated $\mathrm{HCl}$ in $\mathrm{EtOH}$ gave $\mathbf{1 6}(\mathrm{HCl}$ salt

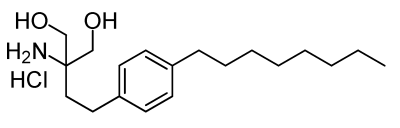

FTY720 (1)

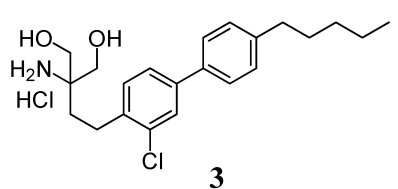

Fig. 1. Structures of FTY720 and FTY720 Analogs 
<smiles>CCCNC(C(=O)OCC)(C(=O)OCC)C(=O)OCC(C)C</smiles>

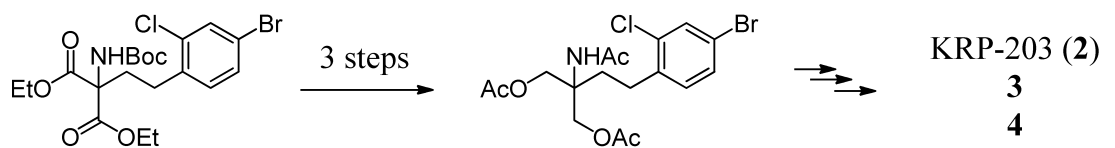

9

10

Chart 1. Previous Synthetic Route of Compound $\mathbf{1 0}$<smiles>CC(=O)NCC(CCc1ccc(Br)cc1Cl)(COC(C)=O)OC(C)=O</smiles>

10<smiles>CC1(C)OCC(C#Cc2ccc(Br)cc2Cl)(NC(=O)c2ccccc2)CO1</smiles>

11

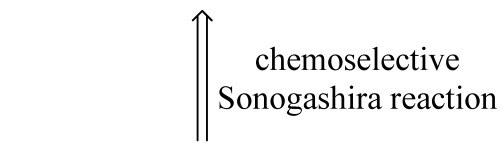<smiles>C#CC1(NC(=O)OCc2ccccc2)COC(C)(C)C1</smiles>

Chart 2. Retrosynthesis of Compound $\mathbf{1 0}$

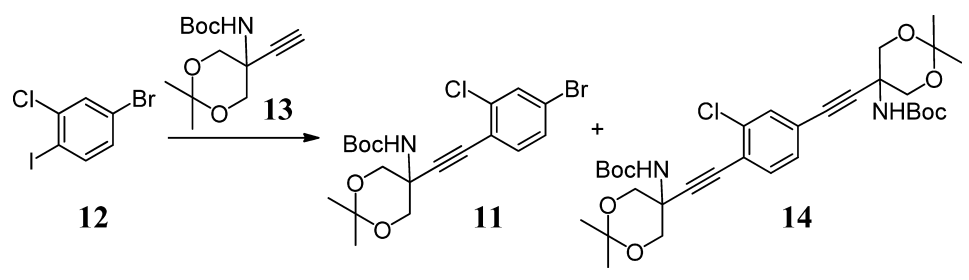

Chart 3

Table 1. Sonogashira Reaction of Trihalobenzene $\mathbf{1 2}$

\begin{tabular}{ccccc}
\hline \hline Run & Temp. $\left({ }^{\circ} \mathrm{C}\right)$ & $\mathbf{1 1}(\%)$ & $\mathbf{1 4}(\%)$ & Rec. 12 $(\%)$ \\
\hline $1^{a)}$ & 50 & & No reaction & 58 \\
$2^{a)}$ & 80 & 53 & 14 & 25 \\
$3^{b)}$ & 80 & 94 & & \\
$4^{c)}$ & 80 & 94 & \\
\hline
\end{tabular}

a) $\mathrm{Pd}\left(\mathrm{CH}_{3} \mathrm{CN}\right)_{2}$, X-Phos, $\mathrm{Cs}_{2} \mathrm{CO}_{3}, \mathrm{MeCN}, 3$ h. $b$ ) Pd( $\left.\mathrm{PPh}_{3}\right)_{4}, \mathrm{CuI}, \mathrm{DMF}-\mathrm{Et}_{3} \mathrm{~N}, 3$ h. $c$ ) $\mathrm{PdCl}_{2}\left(\mathrm{PPh}_{3}\right)_{2}, \mathrm{CuI} \mathrm{PPh}_{3},(i-\mathrm{Pr})_{2} \mathrm{NH}, 3$ h.

of $\mathbf{1 5 b}$ ) as a solid, which was acetylated to give $\mathbf{1 0}$ in good yield.

In conclusion, a concise synthesis of the useful intermediate, compound 10, has been developed (4 steps, 66\% overall yield). The key step was a chemoselective Sonogashira reaction of a trihalobenzene with an alkyne. This route shortened the preparation of $\mathbf{1 0}$ from that previously used and provided easier access to some interesting analogs (e.g., 2-4) for biochemical and pharmacological studies.

\section{Experimental}

Silica gel column chromatography was performed on a Moritex Purif- $\alpha 2$ system using Purif-Pack $30-\mu \mathrm{m}$ or $60-\mu \mathrm{m}$ silica gel columns and the reported solvents as eluents under gradient conditions. ${ }^{1} \mathrm{H}-\mathrm{NMR}$ spectra were recorded on a Bruker AVANCE $400(400 \mathrm{MHz})$ spectrometer. Chemical shifts are expressed in ppm relative to tetramethylsilane (TMS) as an internal standard. Mass spectra were measured in an apparatus comprising a Waters Acquity UPLC system $\left(\mathrm{CH}_{3} \mathrm{CN}+0.05 \%\right.$ trifluoroacetic acid (TFA) $\left./ \mathrm{H}_{2} \mathrm{O}+0.05 \% \mathrm{TFA}\right)$ 


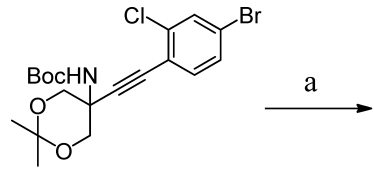

11
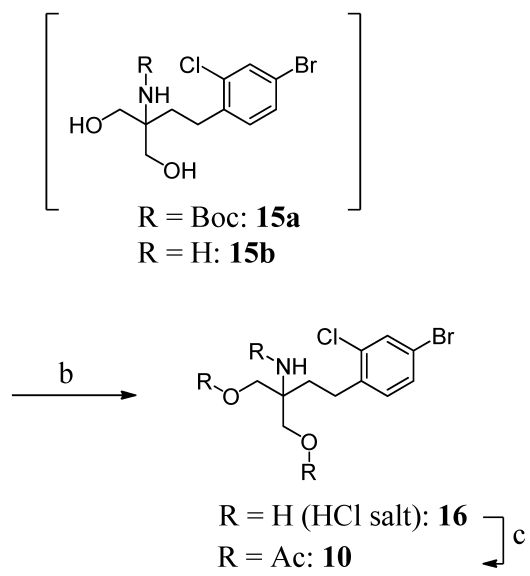

Reagents and conditions: (a) $\mathrm{PtO}_{2}, \mathrm{H}_{2}$, EtOH, rt; (b) concentrated $\mathrm{HCl}, \mathrm{EtOH}, 50{ }^{\circ} \mathrm{C}, 72 \%$ (from 12); (c) $\mathrm{Ac} \mathrm{C}_{2} \mathrm{O}, \mathrm{Py}, \mathrm{rt}, 92 \%$.

Chart 4. Synthesis of Compound $\mathbf{1 0}$ from Alkyne 11

and a Micromass ZQ (electrospray ionization (ESI)) spectrometer. Melting points were obtained on a Büchi 535 melting point apparatus and are uncorrected. Elemental analyses were performed on a Perkin Elmer 2400 II CHN Analyzer.

tert-Butyl 2,2-Dimethyl-5-\{(4-bromo-2-chlorophenyl)ethynyl\}-1,3-dioxan-5-ylcarbamate (11) To a mixture of 12 (317 mg, $1.0 \mathrm{mmol}), \mathrm{PdCl}_{2}\left(\mathrm{PPh}_{3}\right)_{2}(4 \mathrm{mg}, 2 \mathrm{~mol} \%), \mathrm{PPh}_{3}$ $(10.5 \mathrm{mg}, 4 \mathrm{~mol} \%)$, and $\mathrm{CuI}(7.6 \mathrm{mg}, 4 \mathrm{~mol} \%)$ in $(i-P r)_{2} \mathrm{NH}$ $(3.3 \mathrm{~mL})$ was added alkyne $13(281 \mathrm{mg}, 1.1 \mathrm{mmol})$. The mixture was stirred at $80^{\circ} \mathrm{C}$ for $3 \mathrm{~h}$, and EtOAc $(10 \mathrm{~mL})$ was then added. After removal of the precipitate by filtration, the filtrate was diluted with water and extracted with EtOAc $(3 \times 25 \mathrm{~mL})$. The combined organic layers were washed with brine, dried over $\mathrm{Na}_{2} \mathrm{SO}_{4}$, and concentrated in vacuo. The residue was purified by silica gel column chromatography (hexane-EtOAc) to give $11(430 \mathrm{mg}, 94 \%)$ as a pale brown solid.

mp 90-92 ${ }^{\circ} \mathrm{C}$ MS (ESI) m/z: $344[\mathrm{M}-\mathrm{Boc}+\mathrm{H}]^{+} .{ }^{1} \mathrm{H}-\mathrm{NMR}$ $\left(400 \mathrm{MHz}, \mathrm{CDCl}_{3}\right) \delta: 1.45(3 \mathrm{H}, \mathrm{s}), 1.48(9 \mathrm{H}, \mathrm{s}), 1.51(3 \mathrm{H}$, s), $4.06(2 \mathrm{H}, \mathrm{d}, J=11.2 \mathrm{~Hz}), 4.12(2 \mathrm{H}, \mathrm{d}, J=11.2 \mathrm{~Hz}), 5.22$ $(1 \mathrm{H}$, brs), $7.33(2 \mathrm{H}, \mathrm{m}), 7.56(1 \mathrm{H}, \mathrm{s})$. Anal. Calcd for $\mathrm{C}_{19} \mathrm{H}_{23} \mathrm{BrClNO}_{4}$ : C, 51.31; H, 5.21; N, 3.15. Found: C, 51.38; H, $5.14 ; \mathrm{N}, 3.10$.

2-Amino-2-(2-[4-bromo-2-chlorophenyl]ethyl)-1,3propanediol Hydrochloride (16) To a mixture of $12(10 \mathrm{~g}$, $31.5 \mathrm{mmol}), \mathrm{PdCl}_{2}\left(\mathrm{PPh}_{3}\right)_{2} \quad(442 \mathrm{mg}, 2 \mathrm{~mol} \%), \mathrm{PPh}_{3}$ (331 mg, $4 \mathrm{~mol} \%)$, and $\mathrm{CuI}(240 \mathrm{mg}, 4 \mathrm{~mol} \%)$ in $(i-\mathrm{Pr})_{2} \mathrm{NH}(105 \mathrm{~mL})$ was added alkyne $\mathbf{1 3}(8.85 \mathrm{~g}, 1.1 \mathrm{mmol})$. The mixture was stirred at $80^{\circ} \mathrm{C}$ for $4 \mathrm{~h}$, and EtOAc $(50 \mathrm{~mL})$ was then added. After removal of the precipitate by filtration, the filtrate was concentrated in vacuo, diluted with water $(150 \mathrm{~mL})$, and extracted with EtOAc $(150 \mathrm{~mL}, 3 \times 50 \mathrm{~mL})$. The combined organic layers were washed with brine, dried over $\mathrm{Na}_{2} \mathrm{SO}_{4}$, and concentrated in vacuo. The residue was purified by silica gel column chromatography (hexane-EtOAc) to give 11. A mixture of $\mathbf{1 1}$ in EtOH $(140 \mathrm{~mL})$ was stirred under a hydrogen atmosphere in the presence of $\mathrm{PtO}_{2}(700 \mathrm{mg})$ for $24 \mathrm{~h}$ at room temperature. After removal of the catalyst by filtration, the filtrate was concentrated in vacuo. To a solution of the residue in EtOH $(50 \mathrm{~mL})$ was added concentrated $\mathrm{HCl}(10 \mathrm{~mL})$. The mixture was stirred at $50^{\circ} \mathrm{C}$ for $6 \mathrm{~h}$. After the solution was concentrated in vacuo, the residue was collected by filtration to give $16(7.84 \mathrm{~g}, 72 \%)$ as a white solid.

mp $186-188^{\circ} \mathrm{C}$ MS (ESI) $m / z: 308 \quad[\mathrm{M}+\mathrm{H}]^{+} .{ }^{1} \mathrm{H}-\mathrm{NMR}$ $\left(400 \mathrm{MHz}, \mathrm{DMSO}-d_{6}\right) \delta: 1.77(2 \mathrm{H}, \mathrm{dt}, J=8.7,4.6 \mathrm{~Hz}), 2.73$ $(2 \mathrm{H}, \mathrm{dt}, J=8.7,4.6 \mathrm{~Hz}), 3.55(4 \mathrm{H}, \mathrm{d}, J=5.1 \mathrm{~Hz}), 5.44(2 \mathrm{H}$, t, $J=5.1 \mathrm{~Hz}), 7.35(1 \mathrm{H}, \mathrm{d}, J=8.2 \mathrm{~Hz}), 7.52(1 \mathrm{H}, \mathrm{dd}, J=8.2$, $2.0 \mathrm{~Hz}), 7.69(1 \mathrm{H}, \mathrm{d}, J=2.0 \mathrm{~Hz}), 7.96$ (3H, br s). Anal. Calcd for $\mathrm{C}_{11} \mathrm{H}_{15} \mathrm{BrClNO}_{2} \mathrm{HCl}$ : C, 38.29; H, 4.67; N, 4.06; Cl, 20.55; Br, 23.16. Found: C, 38.29; H, 4.67; N, 4.05; Cl, 20.57; Br, 23.09.

2-Acetamido-2-[2-(4-bromo-2-chlorophenyl)ethyl]propane-1,3-diol Diacetate (10) Compound 16 (7.12 g, $20 \mathrm{mmol})$ was dissolved in pyridine $(40 \mathrm{~mL})$. Acetic anhydride $(20 \mathrm{~mL})$ was added to the solution at $0^{\circ} \mathrm{C}$. After stirring at room temperature for $2.5 \mathrm{~h}$, water $(150 \mathrm{~mL})$ was added to the reaction mixture at $0^{\circ} \mathrm{C}$. The mixture was extracted with EtOAc $(150 \mathrm{~mL}, 3 \times 50 \mathrm{~mL})$, and the combined organic layers were washed successively with water, $0.5 \mathrm{~N} \mathrm{HCl}$, saturated $\mathrm{NaHCO}_{3}$, and brine. The organic layer was dried over $\mathrm{Na}_{2} \mathrm{SO}_{4}$ and concentrated in vacuo. The residue was precipitated from EtOH-water $(1: 2)$ to give a solid. Recrystallization from hexane-EtOAc $(40: 1)$ gave $\mathbf{1 0}(8.23 \mathrm{~g}, 92 \%)$ as a white solid.

$\mathrm{mp} \quad 97-99^{\circ} \mathrm{C}$ MS (ESI) $m / z: 434 \quad[\mathrm{M}+\mathrm{H}]^{+} .{ }^{1} \mathrm{H}-\mathrm{NMR}$ $\left(400 \mathrm{MHz}, \mathrm{CDCl}_{3}\right) \delta: 2.00(3 \mathrm{H}, \mathrm{s}), 2.10(6 \mathrm{H}, \mathrm{s}), 2.14(2 \mathrm{H}, \mathrm{dt}$, $J=8.7,4.6 \mathrm{~Hz}), 2.69$ (2H, dt, $J=8.7,4.6 \mathrm{~Hz}), 4.36(4 \mathrm{H}, \mathrm{s}), 5.73$ $(1 \mathrm{H}, \mathrm{brs}), 7.10(1 \mathrm{H}, \mathrm{d}, J=8.2 \mathrm{~Hz}), 7.32(1 \mathrm{H}, \mathrm{dd}, J=8.2,2.0 \mathrm{~Hz})$, $7.50(1 \mathrm{H}, \mathrm{d}, J=2.0 \mathrm{~Hz})$. Anal. Calcd for $\mathrm{C}_{17} \mathrm{H}_{21} \mathrm{BrClNO}_{5}$ : C, 46.97; H, 4.87; N, 3.22; Cl, 8.16; Br, 18.38. Found: C, 47.22; H, $4.84 ; \mathrm{N}, 3.25 ; \mathrm{Cl}, 8.08 ; \mathrm{Br}, 18.20$.

\section{References}

1) Adachi K., Hikawa H., Hamada M., Endoh J., Ishibuchi S., Fujie N., Tanaka M., Sugahara K., Oshita K., Murata M., PCT Int. Appl. WO2006/129623 (2006) [Chem. Abstr., 146, 45546 (2006)].

2) Mehta V. P., Modha S. G., Rujiter E., Van Hecke K., Van Meerwelt L., Pannecouque C., Balzarini J., Orru R. V. A., Van der Eycken E., J. Org. Chem., 76, 2828-2839 (2011).

3) Adachi K., Kohara T., Nakao N., Arita M., Chiba K., Mishina T., Sasaki S., Fujita T., Bioorg. Med. Chem. Lett., 5, 853-856 (1995).

4) Kiuchi M., Adachi K., Kohara T., Minoguchi M., Hanano T., Aoki Y., Mishina T., Arita M., Nakao N., Ohtsuki M., Hoshino Y., Teshima K., Chiba K., Sasaki S., Fujita T., J. Med. Chem., 43, 2946-2961 (2000).

5) Cohen J. A., Barkhof F., Comi G., Hartung H. P., Khatri B. O., Montalban X., Pelletier J., Capra R., Gallo P., Izquierdo G., TielWilck K., de Vera A., Jin J., Stites T., Wu S., Aradhye S., Kappos L., TRANSFORMS Study Group, N. Engl. J. Med., 362, 402-415 (2010). 
6) Adachi K., Chiba K., Perspect. Medicin. Chem., 1, 11-23 (2008).

7) Shimizu H., Takahashi M., Kaneko T., Murakami T., Hakamata Y., Kudou S., Kishi T., Fukuchi K., Iwanami S., Kuriyama K., Yasue T., Enosawa S., Matsumoto K., Takeyoshi I., Morishita Y., Kobayashi E., Circulation, 111, 222-229 (2005).

8) Hamada M., Nakamura M., Kiuchi M., Marukawa K., Tomatsu A., Shimano K., Sato N., Sugahara K., Asayama M., Takagi K., Adachi K., J. Med. Chem., 53, 3154-3168 (2010).

9) Hamada M., Kiuchi M., Adachi K., Synthesis, 1927-1929 (2007).
10) Konishi Y., Ando N., Kuriyama K., Iwanami S., Kudou S., PCT Int. Appl. WO03/029205 (2003) [Chem. Abstr., 138, 304049 (2003)].

11) Kiuchi M., Nakamura M., Hamada M., Sugahara K., PCT Int. Appl. WO2007/126042 (2007) [Chem. Abstr., 147, 521964 (2007)].

12) Kim S., Lee H., Lee M., Lee T., Synthesis, 753-755 (2006)

13) Bytschkov I., Siebeneicher H., Doye S., Eur. J. Org. Chem., 28882902 (2003).

14) Kiuchi M., Tashiro K., Kobayashi N., Sugahara K., PCT Int. Appl. WO2007/069712 (2007) [Chem. Abstr., 147, 95413 (2007)]. 